\title{
COMPUTER MODELING AS AN INSTRUMENT FOR PRE-SERVICE TEACHERS' TRAINING BASED ON HOLISTIC APPROACH
}

\author{
Bilousova L. I., Gryzun L. E.
}

\section{INTRODUCTION}

Learning contemporary state of national pre-service teachers' training reveals a number of serious problems ${ }^{1}$, among which there is a dropping of general desire to earn the teacher's job, lack of teachers who are ready to apply advanced methods and technologies ${ }^{2}$ etc. These problems seem to be especially urgent for the Science and Mathematics teachers' preparation. High level of mathematical and scientific education is seen as a basis for development of key branches of economy which is especially crucial for Ukraine. Nowadays society demands advanced professionals in these areas who are able to apply fundamental knowledge efficiently in active way.

However, according to recent surveys and educational studies, in particular $^{3}$, it is observed using counterproductive approaches to science teachers' education where prevalent methods are still theoretical learning and typical tasks solving, although experimenting, simulation and modeling are rather habitual cognitive ways for these branches. These circumstances seem to cause decreasing interest of potential teachers to their work during their training. Thus, it becomes really important to build the renewed approaches to pre-service teachers' training on the basis of new paradigms.

One of such a paradigm might be the holistic educational approach, which is emphasized in some of normative documents like Education for Sustainable Development Goals: Learning Objectives (UNESCO, 2017) and others. According to works on the holistic theory, the main concept of such education is the integral development of the student's personality at the

Освітня реформа: результати та перспективи. Київ, 2019. URL: https://mon.gov.ua/storage/app/media/Serpneva\%20conferentcia/2019/Institut-osvanalitiki.pdf

${ }^{2}$ Концепція Нової Української Школи. URL: www.nus.org.ua

3 Стан та перспективи розвитку природничо-математичної освіти в системі загальної середньої освіти в Україні. Київ, 2019. URL: http://www.soippo.edu.ua/ index.php/home/3589-stan-i-perspektivi-rozvitku-prirodnicho-matematichnoji-osviti-vsistemi-zagalnoji-serednoji-osviti-v-ukrajini 
intellectual and emotional levels simultaneously ${ }^{4}$. It is also emphasised that the said integral development is based on the links between personal cognitive experience and dealing with real-life tasks.

The set of theoretical studies ${ }^{56}$, allow to formulate core principles of holistic paradigm which seem to be relevant in terms of modernization of Science and Mathematics teachers' training.

The first principle provides students' autonomy and freedom which means that a trainee is thought to be an active participant of the learning process who explores the reality through direct interaction with it and via own cognitive activity.

Next essential principle of the holistic education focuses on establishing connections between the object of learning and earned knowledge. Links making during learning provides forming of strong memories in the trainees' minds and efficient understanding of the reality wholeness. As a result, students obtain concentrated holistic knowledge, what is crucial for potential science and Math teachers who must be able to form such knowledge in schoolchildren's minds in their future professional activity.

The principle of transdiciplinarity concentrates cognitive process on removing frontiers between subject areas and between subject areas and reality. Experts in holistic education emphasize the necessity to realize both principles (of connection and transdiciplinarity) together, as it is really beneficial to learn separate things which are not separate in fact, and at the same time, to realize how they work together.

The analysis of the holistic education principles which makes a theoretical background of the work testifies necessity to apply efficient instruments for such an approach implementation into the process of potential teachers' training.

One of the instruments seems to be computer modeling which expects both models building and simulation activity with them. According to didactic studies ${ }^{7}$ revealing core benefits of computer modeling, it has high potential as for revealing inter-disciplinary links and facilitating their understanding by trainees. In addition, it is emphasized ${ }^{8}$ that computer

${ }^{4}$ Singh, K. : Education for the Global Society', in Learning: The Treasure Within, The Report to UNESCO of the International Commission on Education for the Twenty First Century, Paris: UNESCO. 1996.

${ }^{5}$ Mahmoudi, S., Jafari, E., Nasrabadi, H., Liaghatdar, M.: Holistic Education: An Approach for 21 Century. International Education Studies, v. 5, n. 2, p. 178-186. 2012.

${ }^{6}$ Miller, J.: Holistic learning and spirituality in education: Breaking new ground. Albany: State University of New York Press. New York Press Ed. 2005.

7 Hacker M. Integrating computational thinking into technology and engineering education. Technology and Engineering Teacher, 2018. 77 (4), 8-14.

8 Зайцев Д.А. Математичні моделі дискретних систем: навчальний посібник. Одеса: ОНАЗ імені О. Попова, 2004. 40 с. 
models basing on the mathematical model of a phenomenon (process, concept, etc.) allow visualizing its peculiarities in real time, learning the behavior of the whole system dynamically, and investigate it through active cognition ${ }^{9}$. Thus, computer modeling and simulation (1) contributes to forming and developing trainees' techniques of mental activity including inter-disciplinary one; (2) encourages trainees to reveal and demonstrate in action the wholeness of the modeled concepts (processes), learning them independently and actively at the same time; (3) provides facilities of thought-provoking dynamic modification of the model, developing the trainees' inquisitional eagerness and intuition ${ }^{10}$, what is really crucial in the context of contemporary teachers' training.

Minding the said benefits of computer modeling and advantages of project-oriented activity in terms of modernization of pre-service teachers' training based on holistic approach, we involved our students (pre-service Science and Math teachers) in the project activity focused on the computer models building and simulation activities.

The aim of the paper is to cover practical aspects of students' projectoriented activity on computer models building and simulation in terms of holistic approach realization, and to highlight the empirical research done on purpose of revealing influence of this kind of activity on the results of students' holistic training.

\section{Practical aspects of pre-service teachers' project-oriented activity on computer modelling}

As it was said above, within the model of modernization of pre-service teachers' training based on holistic approach, our students (who are potential Science and Mathematics teachers) are involved into the project activity within their independent work on some of curriculum subjects. The projects topics offered to the students are different, but all of them are focused on the design of computer dynamic models for learning various concepts (processes, phenomena). Thus, all the projects embrace similar stages presented below.

At the initial stage of a project, mathematical model of the future computer model is built by the students as a set of steps: (1) revealing the essence of the concept (phenomena), its links with other ones (mathematical and non-mathematical concepts); (2) obtaining dependencies allowing to illustrate and investigate the concept; (3) revealing the fixed model

${ }^{9}$ Shamshina Natalia. Solving Tasks Of Computer Modeling In Excel Spreadsheet. Physical and Mathematical Education. 2018. Issue 4(18). P. 171-176.

${ }^{10}$ Balogh Z., Kuchárik M.: Student Learning Simulation Process with Petri Nets: Proceedings of ICCD. 2017. URL: https://www.researchgate.net/publication/327188084_ Student_Learning_Simulation_Process_with_Petri_Nets_Proceedings_of_ICCD_2017 
parameters and changeable ones as well as the scope and steps of their changes; (4) determining special graphic components enable to demonstrate model behaviour dynamically; (5) inventing the problems which are relevant to solve using the model.

At the second phase the mathematical model is transformed into computer one by the means of proper software. In particular, students worked within environments of MS Excel, GeoGebra, Pertri Nets application and others.

The next stage of the project is focused on the debugging, testing, and elaboration of the model.

At the following stage students are encouraged to develop proper didactic support for the implementation of the holistic approach which includes the set of specific tasks for trainees. Here students develop (1) the plan of trainees' work with the model, aimed at realizing the essence of the concept; (2) the plan of necessary computing experiment; (3) learning material which is offered trainees as an explanation, heuristic questions that should be asked, summary of the results of simulation activities etc. Students also integrate the developed didactic support into the environment of the dynamic model using proper controls components and adjust the interface of the models.

The final stage of the project is devoted to the trial and analysis of the results of its implementation. Thus, the said stages of the projects testify that the students are exposed to the complex of cognitive activities: they are expected to create the dynamic computer models themselves, practicing in such a way their own modelling skills; to experience their own simulation and investigation activities, and to prepare special didactic support which enabled them to involve their potential trainees into manipulating the created models and learning the modelled objects.

The practical aspects and experience of the said project-oriented activity are covered below on the concrete examples of students' projects on computer dynamic modelling.

The first project task was to develop the complex of computer transdisciplinary models for schoolchildren. The models in the complex built in GeoGebra software were grouped in the categories according to the school curriculum disciplines (Physics, Algebra, Geometry, Informatics, Biology, Geography). Main page of the complex and some of its categories are given on the Figures 1-2. 
$\equiv$ GerGebra

Комплекс комп'ютерних динамічних моя

Фізика

Алгебра

Геометрія

Біологія

Географія

Хімія

Інформатика
Комплекс комп'ютерних динамічних моделей

Author: Дарья

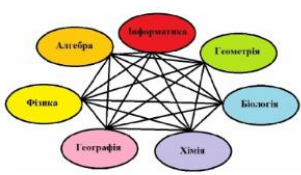

Table of Contents

Фізика

Оптична лінза

Ліфт

Математичний маятник

Модель "Стріль6а з гармати"

Fig. 1. Main page of the computer models complex (Project 1)

$\equiv$ GeoGebra

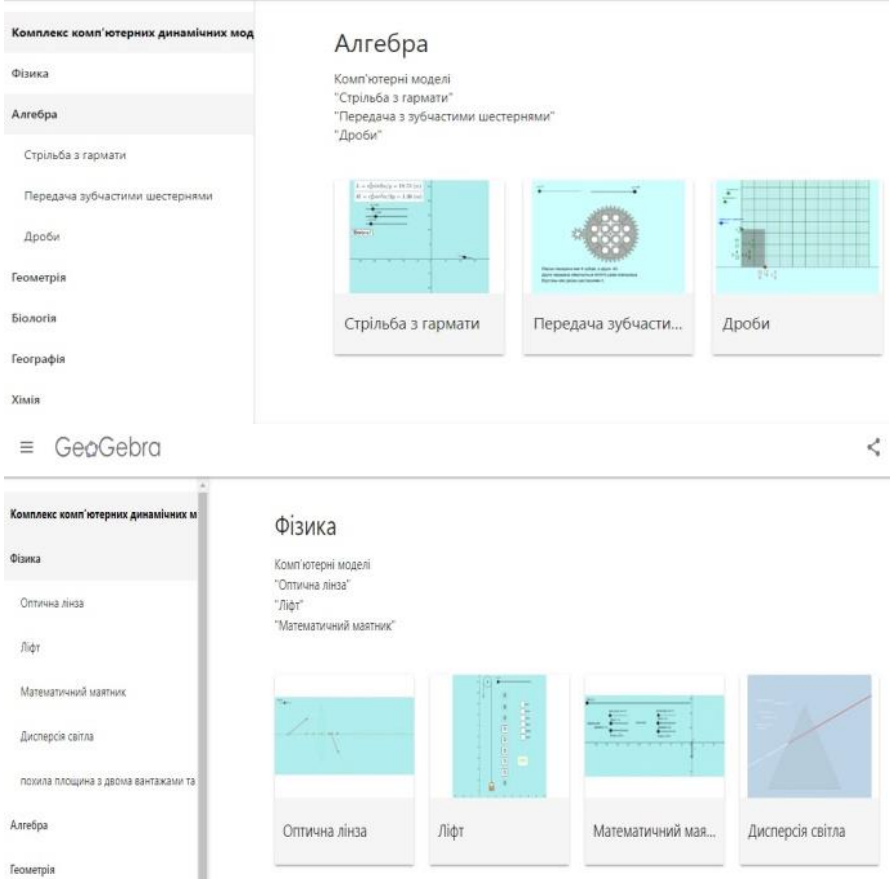

Fig. 2. Episodes of work with Algebra and Physics categories of the computer models complex (Project 1) 
Each of the model was designed and put in the complex according to the common order. In particular, all the models provide: chain of the transdisciplinary links covered by the model; model description depicting concept (phenomenon) that makes a prototype of the model; dynamic model along with its functionality; didactic support (the number of interdisciplinary tasks and real-life problems focused on creating holistic image of the concept; graph visualizing the links between concepts for remembering holistic representation.

Some of the models are included into several subject categories, but specific didactic support for the models matches proper category and focuses on the subject essence of the modeled concept and different transdisciplinary links.

Some models from various categories of the complex, created by our students, are covered fragmentary below.

For example, it is a model "Clock" (Geometry category) which covers the chain of the links: Geometry-Algebra-Physics. The elaborated by the students didactic support includes the number of transdisciplinary and reallife tasks like these ones.

Task 1. Manipulate the model, move the clock hands, set the time (shown in the figure) and define degree measure of the angles made by the clock hands.

Task 2. Operate the model with various parameters and figure out degree measure of: (1) the angle which makes a third of the right angle, (2) the angle three fifth (five sixth) of which make a right angle, (3) the angle which makes $40 \%(60 \%)$ of a flat angle etc.

Task 3. Use the model to express the given values of speed in the measure of $\mathrm{m} / \mathrm{c}: 60 \mathrm{~km} / \mathrm{h} ; 6 \mathrm{~m} / \mathrm{min} ; 3600 \mathrm{~cm} / \mathrm{min}$ etc.

Task 4. Operating the model, solve the task which shows that a clock is a device that measures time as a social value: Vita and Lina decided to text congratulation messages to his friend Alex. Vita texts 240 words per 6 min, and Lina -350 words per $7 \mathrm{~min}$. Who is quicker, and whose message will Alex get earlier if Vita sent a message of 30 greeting words, and Lina - 20 ones?

Episodes of the tasks solving and the model manipulating are shown on the Figure 3.

Thus, it is clear that the highlighted transdisciplinary tasks for work with the model, developed by the students, are able to form holistic understanding by the potential trainees of (1) time as a physical concept and social phenomenon, (2) a clock as a physical device with geometrical basis, (3) geometrical, algebraic and "time" sense of degree measure of an angle.

The elaborated by the students complex of transdisciplinary computer models includes also some other beneficial models like model "Cannon" which covers links chain: Algebra-Physics-Geometry-History (Figure 4); model "Lens" illustrating the chain of the transdisciplinary connections: Physics-Geometry-Algebra-Biology (Figure 5); model "Number systems" covering links chain: Informatics-Algebra (Figure 6) and others. 


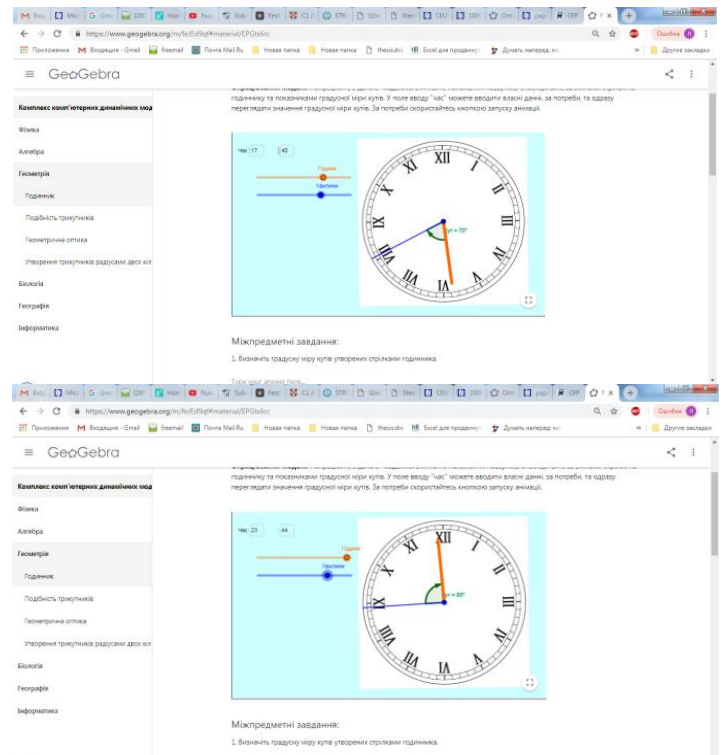

Fig. 3. Episodes of the tasks solving and the model "Clock" manipulating

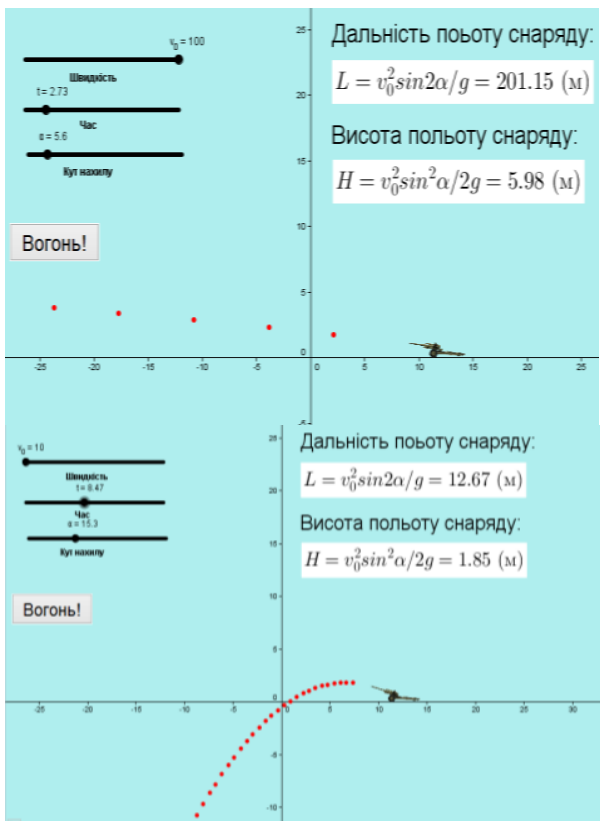

Fig. 4. Fragments of transdisciplinary tasks solving with the model "Cannon" 


\section{Як ми бачимо?}
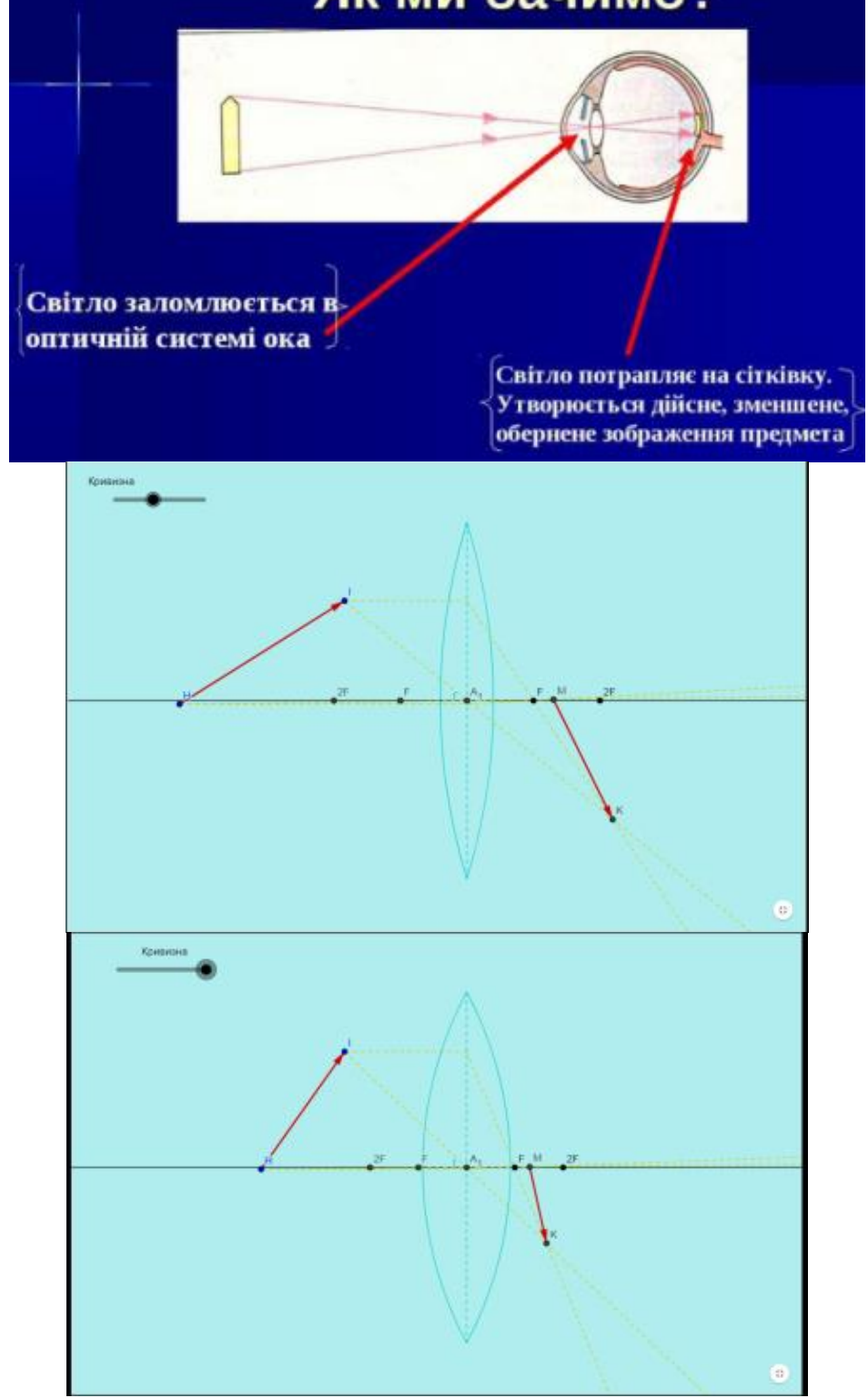

Fig. 5. Fragments of transdisciplinary tasks solving with the model "Lens" 


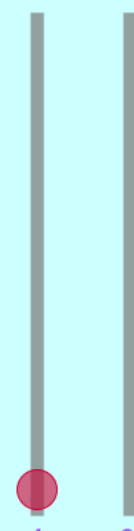

1

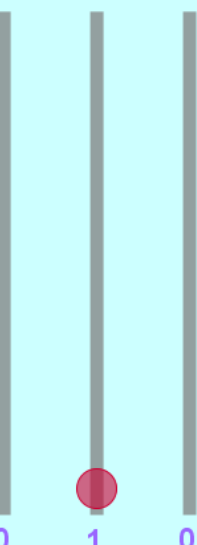

1

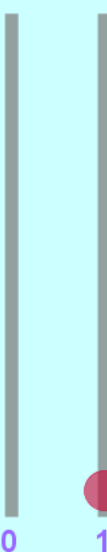

1

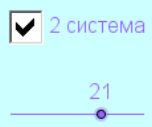

Обчислення

10101

$1 \cdot 16+0 \cdot 8+1 \cdot 4+0 \cdot 2+1$

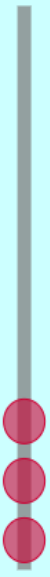

3
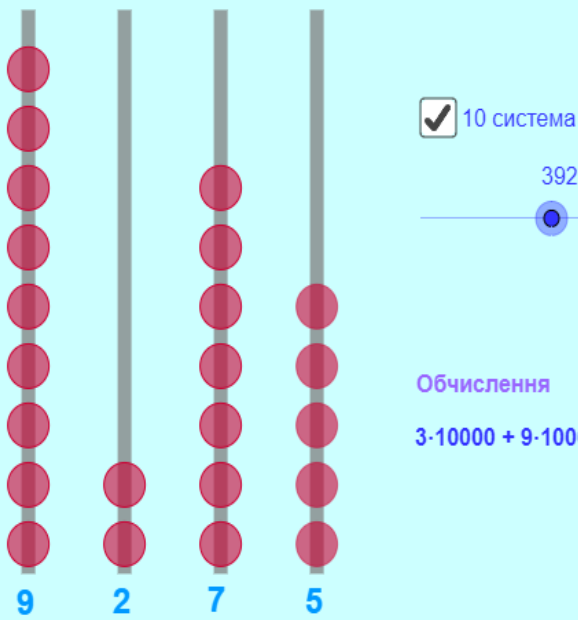

39275

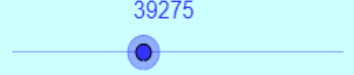

Обчислення

$3 \cdot 10000+9 \cdot 1000+2 \cdot 100+7 \cdot 10+5$

Fig. 6. Fragments of transdisciplinary tasks doing and the model "Numeric systems" manipulating

Thus, students' project activity within the Project 1 provides realization of main principles of the holistic education as it facilitates interdisciplinary links establishing and keeping, focuses on the ruining frontiers between subject areas and reality, provokes pre-service teachers' personal cognitive activity, prepares them for holistic teaching their school pupils in future professional life. It seems to be relevant to predict positive influence of such models design on the forming of students' holistic system of knowledge and skills. 
Our next example of students' modelling activity in terms of holistic approach is the Project 2 which task was to develop the complex of the dynamic models directed on the mastering of a number of abstract mathematical concepts. They were created by the students in MS Excel environment with the elements of VBA programming, what allowed to make the models dynamic ones. In the process of their developing students, like in previous project, were involved in 1) the mathematical model building; 2 ) its visualization in dynamic computer model; 3) research tasks inventing to manipulate the model and learn the concepts in holistic way. As a result of the Project 2, the model complex embraces four groups of models which functionality is fragmentally covered below.

Group 1 (Models 1-3) is focused on visualization of the derivative concept facilitating the understanding its essence in the context of its relations to the limit notion, its geometric interpretation and physical one.

Group 2 (Models 4-5) aims at learning the notions of the function continuity and discontinuity. In particular, the model "Continuity of the function" and its didactic support developed by the students encourages potential trainees to make a conclusion as for the links between function continuity and existence of the derivative at a point. It also helps trainees to realize the reasons of the function discontinuity due to the exploration based on the dynamic manipulations with the model "Discontinuity of the function".

Group 3 (Models 6-8) serves to explore simultaneously the growth and decline of a function, the behavior of the tangent to the curve at passing the points of the function maximum and minimum. The necessary and sufficient conditions for the extremum existence are encouraged to be formulated and realized by potential trainees with the help of the tasks of the didactic support to the models.

Group 4. (Models 9-11) is focused on the realization of a definite integral concept, awareness of its geometric interpretation, and exploring its properties.

The episodes of cognitive activity based on manipulating the models from different groups and solving of explosative tasks from their didactic support are shown at the Figures 7-9.

Thus, students' Project 2 activity allowed them: to practice their own modelling skills; to find the ways how to visualize abstract mathematical concepts and to realize them better; to establish connections between concepts efficiently in their minds; to realize sufficiently their personal cognitive activity; to stimulate their investigative intuition thanks to creating the explorative tasks of the models' didactic support.

Among the projects offered to the pre-service Science and Mathematics teachers in terms of their holistic training there was also a project (Project 3 ) focused on the modelling of the parallel processes with the help of Petri nets. 


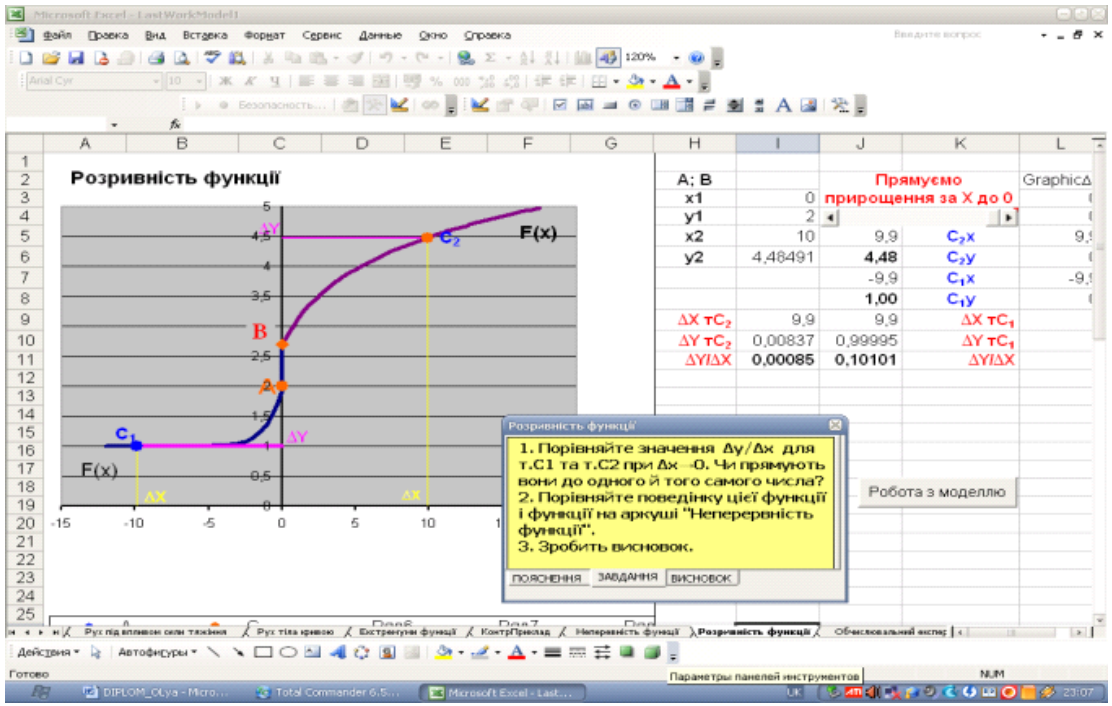

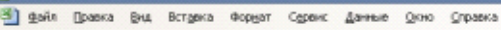

]

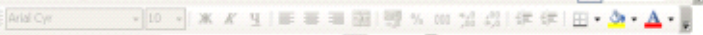

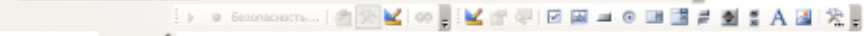

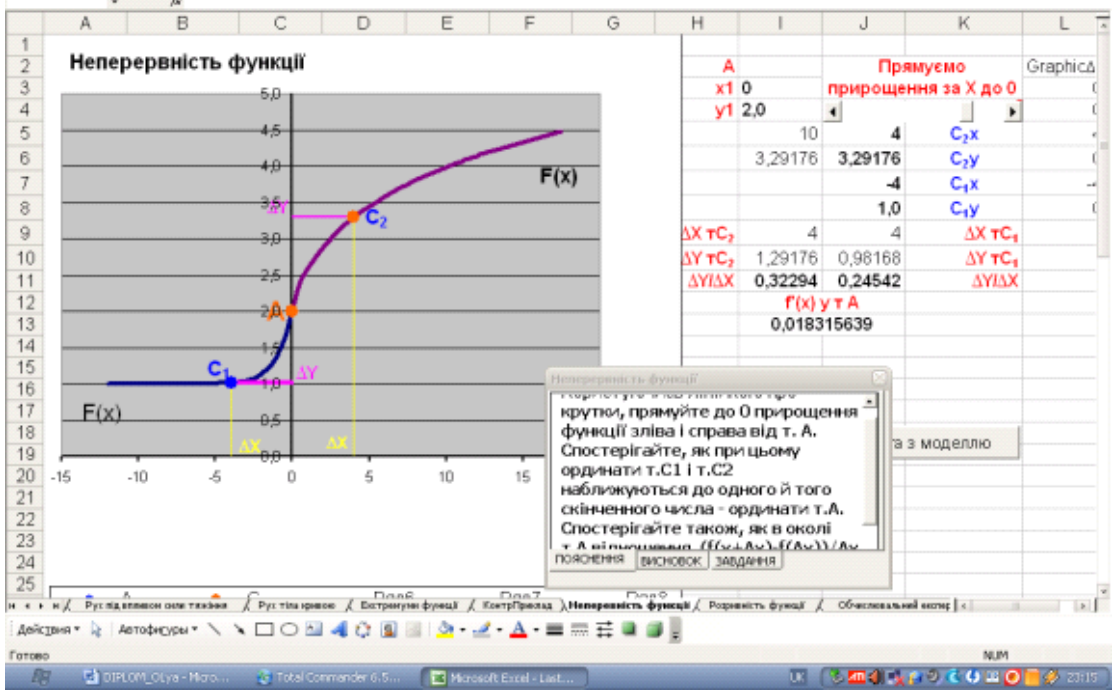

Fig. 7. Fragments of exploring the concepts of function continuity (discontinuity) with the models of Group 2 (Models 4-5) 


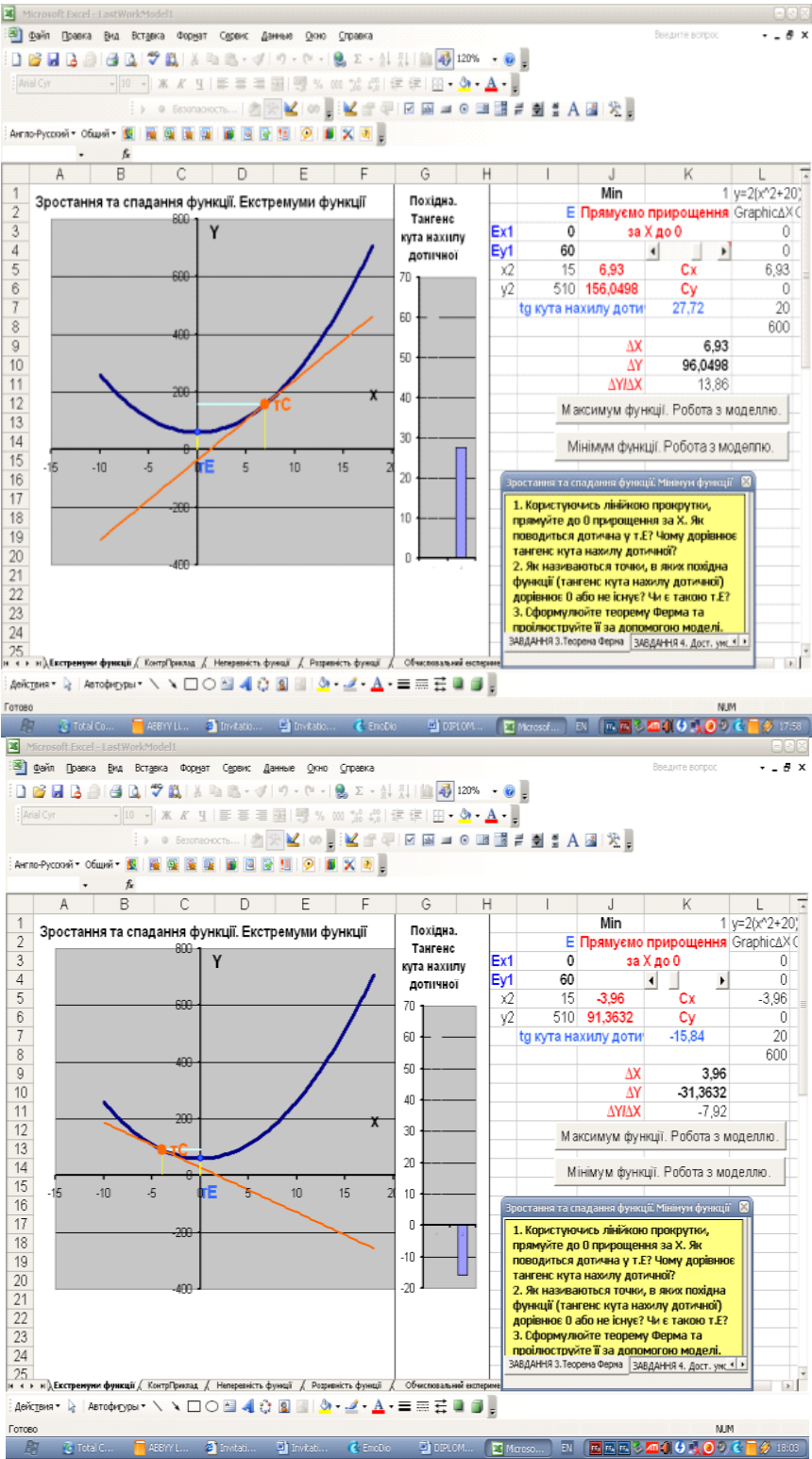

Fig. 8. Fragments of operating the models of Group 3. Model 6. "Extremums" 


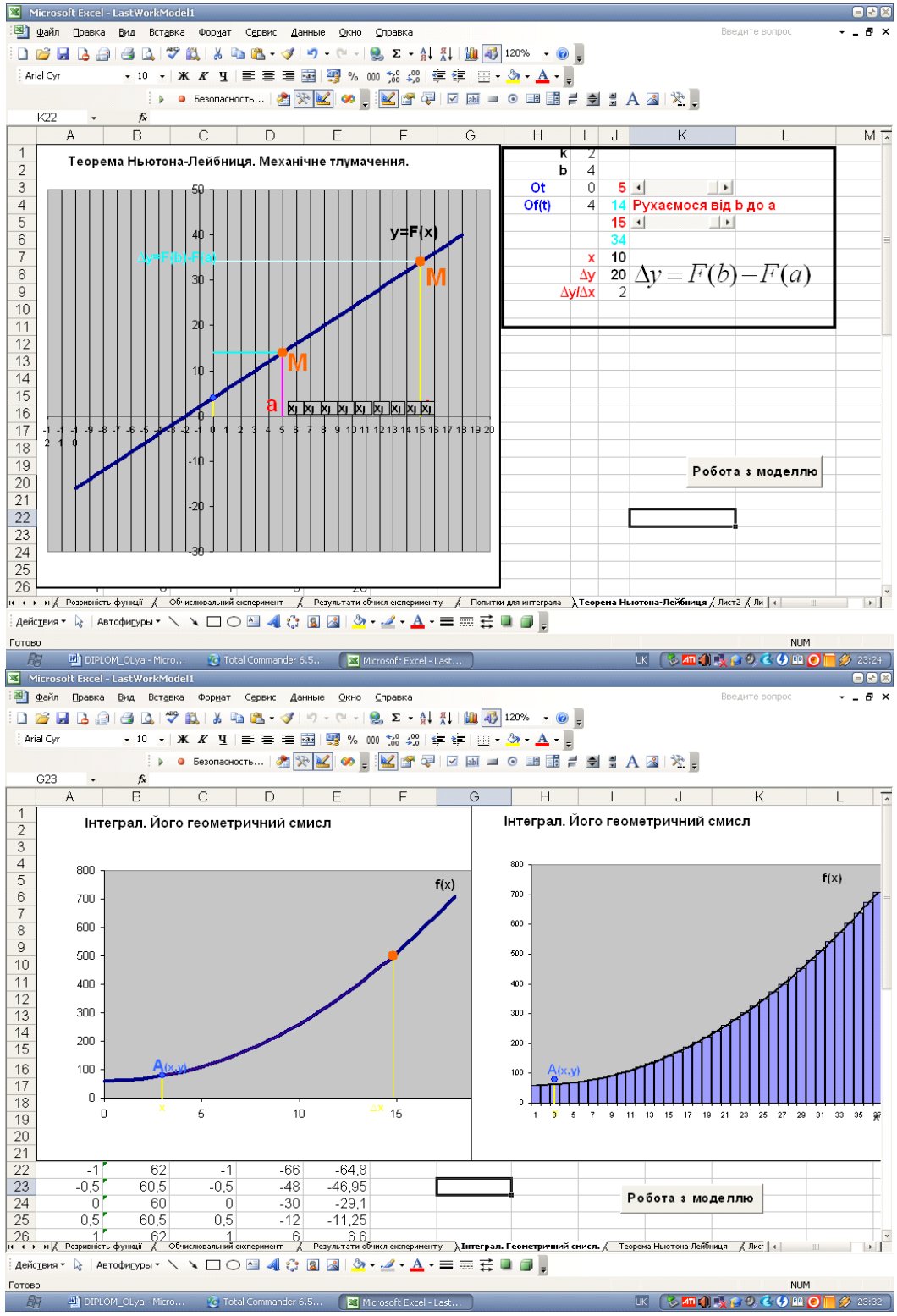

Fig. 9. Fragments of elaborating the models of Group 4. Model 9. "Definite integral concept" 
According to studies ${ }^{11}$, a Petri net is defined as a two-partite oriented graph $\mathrm{N}$ made of finite nonempty sets of a graph vertices of two types: places $\mathrm{P}=\{\mathrm{pi}\}$, and transitions $\mathrm{T}=\{\mathrm{ti}\}$. There is also a component which determines a relationship between the vertices of both types. In a graphical representation of a Petri net, places $\mathrm{P}$ are indicated with circles, transitions $\mathrm{T}$ are signed with bars, and relationships correspond to the arcs of the net ${ }^{12}$.

There are some rules on the Petri net which allow imitating dynamics of the modeled process (phenomena). In particular, the places are able to accommodate so called tokens that can move around the net through transitions. Disposition of tokens in places is determined by the marking function M. Various markings of the Petri net depict the states of the modeled dynamic system. In fact, the number of tokens and their disposition around the net are able to manage the net execution ${ }^{13}$.

Thus, the analysis of Petri nets formalism testifies that it provides mighty facilities for dynamic models building which consequently causes comprehensive exploring of the modeled process peculiarities, what is crucial from the standpoint of Petri nets educational applications ${ }^{14}$.

In particular, this mathematical tool provides intuitively transparent means corresponding to real processes components and their relationships along with interaction, what facilitates creation of the real process model. Additionally, Petri nets are able to visualize dynamic interaction of the process elements which can be demonstrated in its computer interpretation. On the whole, opportunities to manipulate the nets parameters and to change its state with observing immediate changes of the whole system behavior make Petri nets really powerful tool for students' training in the lines of advancing their modeling skills.

Based on Petri nets theory and their modeling advantages, the mobile application "Petri Nets: just do it" was developed in our department and involved into the students' project activity in terms of holistic training.

The application provides a user means to create your own Petri net to model a process: to display necessary places, transitions, arcs, and to determine initial marking of the net; to test, execute and improve the built

${ }^{11}$ Peterson J. Petri net theory and the modeling of systems, Prentice Hall; 1St Edition edition, 1981. $290 \mathrm{p}$.

${ }_{12}$ Petri Carl Adam; Reisig Wolfgang. Petri net. Scholarpedia. 2008. 3 (4): 6477. DOI: $10.4249 /$ scholarpedia.6477

${ }^{13}$ Zaitsev D.A. Toward the Minimal Universal Petri Net. IEEE Transactions on Systems, Man, and Cybernetics: Systems. 2013. 44: p. 47-58. DOI: 10.1109/TSMC.2012.2237549

${ }^{14}$ Rogério Campos-Rebelo, Anikó Costa, Luís Gomes. Finding Learning Paths Using Petri Nets Modeling Applicable to E-Learning Platforms. 3rd Doctoral Conference on Computing, Electrical and Industrial Systems (DoCEIS), Costa de Caparica, Portugal. 2012. pp. 151-160. 
net; to elaborate and explore the modeled process modifying the net parameters and simulating different scenarios of the process development.

Hence, within the Project 3 students were offered to model some specific processes with their explorations. In particular, students were encouraged to model the work of some common devices, to imitate the work of basic algorithm structures, to model the mass service and technological processes etc.

Various episodes of students' activity within the Project 3 are presented in Figures 10-11.

For example, it was asked to create a model of the process of passing a colloquial test by $\mathrm{N}$ students to one teacher. Then it is beneficial to explore different evolutions, when all students are waiting for their turn to talk to teacher, two students are waiting, one student is communicating with the teacher, and one student has already accomplished his interaction with the teacher, three students are ready to pass the test and one student is waiting etc. (Figure 10).

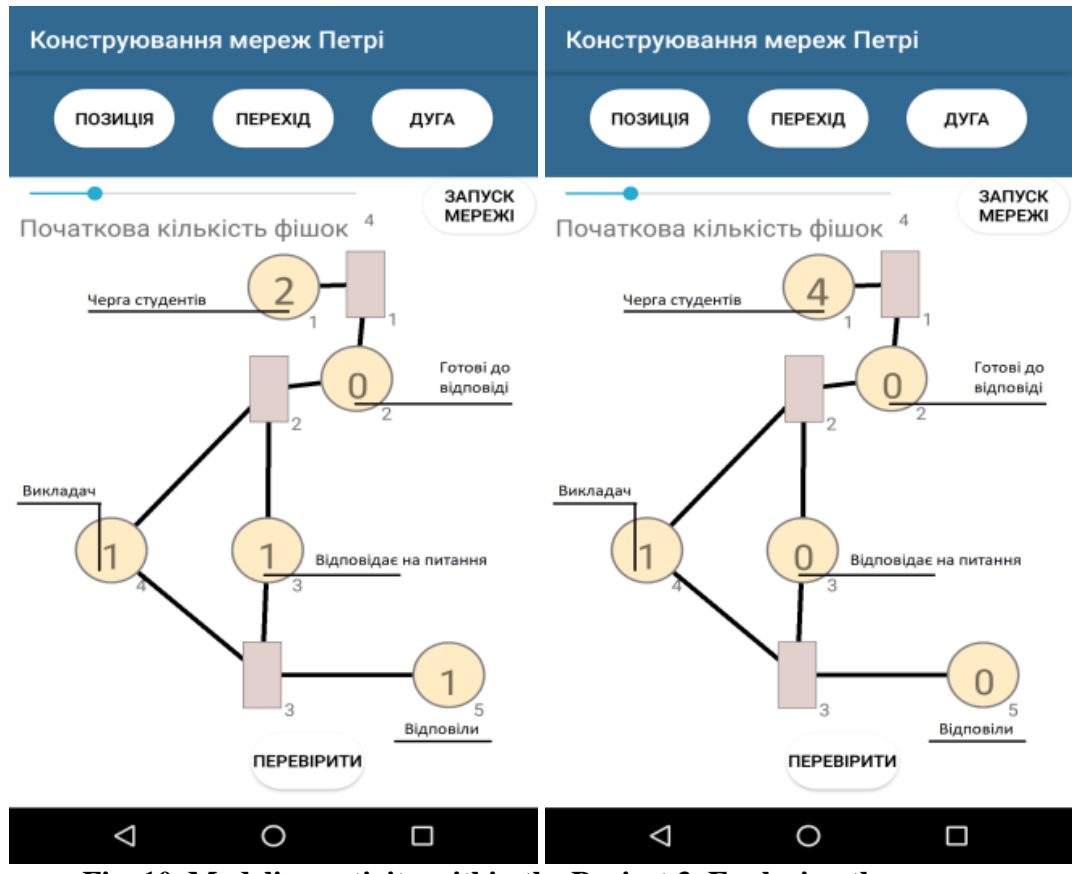

Fig. 10. Modeling activity within the Project 3. Exploring the process of passing a colloquial test by $\mathrm{N}$ students to one teacher 

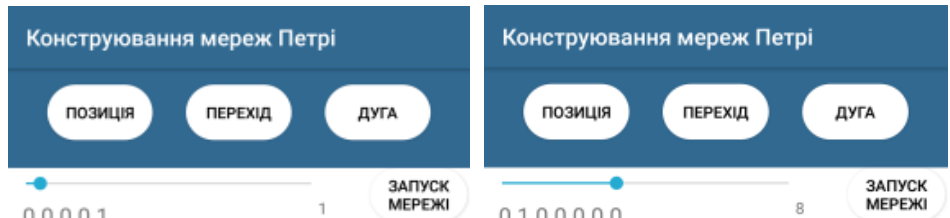

00001

3AПYCK
MEPEXI

0100000

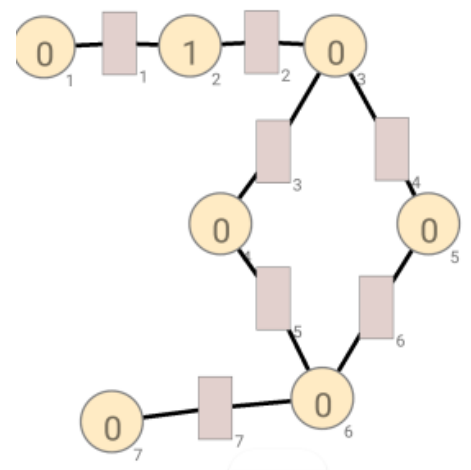

ПЕРЕВIРИTИ

ПЕРЕВIРИTИ

$\triangleleft$

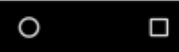

$\square$

$\triangleleft \quad \circ \quad \square$

Конструктор

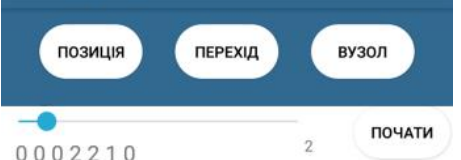

0002210

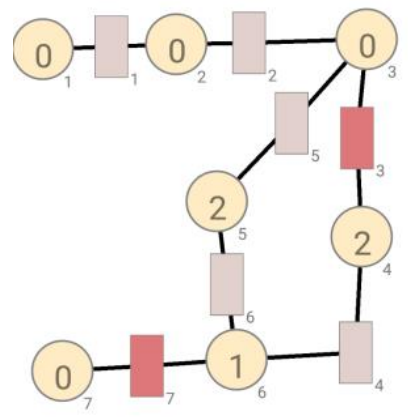

ПЕРЕВIРИTИ

\section{$\triangleleft$}

O

$\square$

Fig. 11. Various episodes of students' activity within the Project 3. Modeling of the railway traffic 
Thus, students' modeling and simulation activities within the Project 3 revealed the benefits of such a modeling in terms of holistic training. In particular, modeling with the Petri nets help:

- stimulated pre-service teachers' interest as for processes imitating and exploring their different scenarios along with their constructive estimation;

- advanced students' modeling and investigative skills, and involved them into enquiry-based learning;

- helped to establish efficiently connections between process components;

- stimulated, as a result, personal cognitive eagerness;

- gave the pre-service teachers personal experience of processes simulation with Petri nets which might be used them in their future teaching.

Summarizing depicted Projects 1-3 (minding also other similar projects), we would like to emphasize some definite benefits for pre-service Science and Mathematics teachers' holistic training. Through the project tasks on modeling the students were involved into the complex of cognitive activities. In particular, pre-service teachers (1) practiced their own modelling skills, (2) experienced their own simulation and investigation activities, (3) prepared special didactic support to involve their potential trainees into manipulating the created models and learning them. Thus, computer modelling encouraged students to reveal and demonstrate in action the wholeness of the modelled concepts (phenomenon), learning them independently and actively, what is really crucial in the context of holistic education.

Hence, it is relevant to predict that the project-oriented activity on building dynamic computer models and simulation activity with them may have positive influence on the results of students' holistic training. The empirical research on this purpose was done which details are covered below.

\section{The empirical research on purpose of the revealing the impact of computer modeling on the results of the holistic training of pre-service teachers}

The said empirical research was provided with pre-service Science and Mathematics teachers (in total 100 students of two departments of G.S. Skovoroda Kharkiv national pedagogical university).

Proper criteria system was elaborated basing on some reasons. According to the aims and facilities of the project-oriented activity depicted above, we can predict that building dynamic computer models and simulation with them may promote for the students: effective creation of links between concepts; increase of functional links quantity in the area of concentrated conceptual knowledge; efficient satisfaction of personal cognitive needs.

Thus, the quotients that can characterize the results of pre-service teachers' holistic professional training including their formed readiness to 
promote the creation of holistic knowledge system in their future pupils' minds, can be students' knowledge characteristics (depth and systemacy) and their cognitive eagerness.

Within the current paper we would like to concentrate on the investigation of exactly cognitive eagerness of the research participants. We focused on this quotient exploring because, as was emphasized in the Introduction, one of the core problem of the Math and Science teachers' preparation is decreasing their eagerness to learn their main subjects during professional training and, consequently, losing the interest to their future job. Our observations of the students' behavior and performance during their project activity testified the growth of their eagerness to learn actively, to find out, test and explore knowledge independently and enthusiastically. On balance, we could predict positive changes in their cognitive eagerness.

In order to explore the influence of computer modeling on the formation of students' cognitive eagerness, we elaborated the system of criteria, their indicators and means of their detecting. According to the criteria system, it became possible to determine the type of the formed student's cognitive eagerness: realized creative, realized constructive, realized executive, or potential (unrealized). It was developed special monitoring program which enabled to learn the students' expressions of the criteria and their indicators during classroom and extra-curricular activity.

The monitoring program expected revealing and exploring the indicators of students' cognitive eagerness:

(1) raising questions and their kinds (clarifying, explaining, in-depth queries as for the essence of knowledge elements and establishing kinks between components of knowledge etc.);

(2) students' desire to reveal their own knowledge (awareness in the current material) and its way (responding questions, solving typical tasks (problems), demonstrating original way of problem solving, in-depth remarks to other's answers, applying knowledge from additional information resources);

(3) initiative (eagerness to solve tasks including optional ones, knowledge applying in various contexts, conscious selection of optimal and productive ways of getting results);

(4) endurance of cognitive initiative (permanent (or episodical) revealing of cognitive eagerness);

(5) student's behavior at meeting difficulties at learning (giving up doing the task, asking for help and carrying on doing the task, going on trials to overcome the difficulty independently);

(6) attracting knowledge from optional and additional information resources (on occasional or regular base);

(7) taking part in extra-curriculum learning activity (episodically, voluntarily but episodically, voluntarily and regularly). 
The scale of indicators detecting was determined. According to it, we could detect the type of the revealed student's cognitive eagerness: realized creative (25-21 grades), realized constructive (20-15 grades), realized executive (14-11 grades), potential (10-5 grades).

At next stage of the empirical research there were formed experimental (EG) and control (CG) groups of pre-service teachers (50 students each one). Their cognitive eagerness was measured before involving the EG students into the project activity on computer modeling. It was confirmed (with nonparametric statistical methods) that the groups' statistical difference from the standpoint of the criteria quotients is not significant. Then EG students were exposed to the project activity within their independent work on some of curriculum subjects in the way it was depicted above. CG students studied according to the common approach.

At the final stage of the empirical research revealed student's cognitive eagerness in both groups again was measured and compared. There were detected the positive changes of students' cognitive eagerness. In particular, the difference of average growth of students' number of EG and CG, who revealed realized creative type of cognitive eagerness is $10.4 \%$, and realized constructive type of cognitive eagerness is $8.0 \%$. It is also observed the $20.2 \%$ decrease of EG student's number, who displayed potential type of cognitive eagerness, whereas in CG this drop made $10.1 \%$. The results of comparing of average growth of students' cognitive eagerness in EG and CG are presented at the Figure 12.

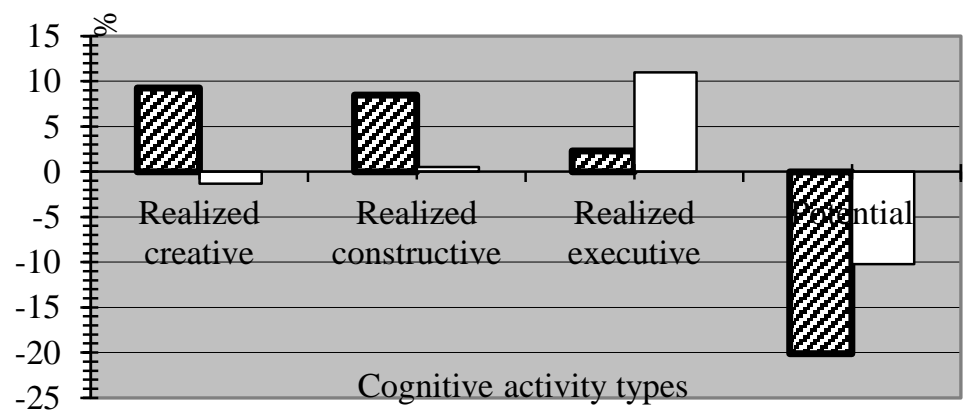

DCognitive eagerness growth in EG

Cognitive eagerness growth in CEG

Fig. 12. Comparing of average growth of students' cognitive eagerness in EG and CG 
The results from Pearson's chi-squared test indicated that the obtained difference in students' cognitive eagerness was significant in statistic sense $(\mathrm{p}=0.05, \mathrm{df}=4)$. Thus, the empirical research demonstrated positive impact of the implemented project-oriented activity on building dynamic computer models and simulation activity with them on the results of students' holistic training, in particular, on their cognitive eagerness.

\section{CONCLUSIONS}

In accordance with the aims of the paper, practical aspects of students' (pre-service Science and Mathematics teachers') project-oriented activity on computer models building and simulation in terms of holistic approach realization are presented. The common stages and structure of all the projects are covered and characterized in details. The general projectoriented activity is specified on concrete examples of students' projects on computer dynamic modelling. In particular, the work upon the project and their results are presented for three projects realized within different software environments:

Project 1. Complex of computer transdisciplinary models for schoolchildren (GeoGebra);

Project 2. Complex of the dynamic models directed on the mastering of a number of abstract mathematical concepts (MS Excel);

Project 3. Modelling of the parallel processes using Petri nets (special mobile application "Petri nets: just do it").

The paper also highlights the stages and results of the empirical research done on purpose of revealing the influence of this kind of activity on the results of students' holistic training. In particular, criteria system for the research is presented, and the proper quotients (students' knowledge characteristics and their cognitive eagerness) are determined. The current paper is concentrated on the investigation of exactly cognitive eagerness of the research participants. As a result, the types of the formed student's cognitive eagerness were detected and analyzed. The empirical research demonstrated positive impact of the implemented project-oriented activity on building dynamic computer models and simulation activity with them on the results of students' holistic training, in particular, on their cognitive eagerness.

The scopes of further research may include development of new prospective topics of projects in various computer environments, elaboration of their stages, and the investigation of the influence of the said activity on the students' knowledge characteristics (depth and systemacy) and their readiness to implement similar activity to the professional teaching in future. 


\section{SUMMARY}

Learning the problems of contemporary national pre-service teachers' training reveals needs for changes of mainstream educational paradigm. One of such a paradigm might be the holistic educational approach. The analysis of the holistic education principles (which makes a theoretical background of the work) testifies necessity to apply efficient instruments for such an approach implementation into nowadays practice of Science and Mathematics teachers' training. One of the instruments seems to be computer modeling which expects both models building and simulation activity with them. According to didactic studies, core benefits of computer modeling in terms of holistic education are revealed. Minding the said benefits of computer modeling and advantages of project-oriented activity in terms of modernization of pre-service teachers' training based on holistic approach, we involved our students (pre-service Science and Math teachers) in the project activity focused on the computer models building and simulation activities. The aim of the paper is to cover practical aspects of students' project-oriented activity on computer models building and simulation in terms of holistic approach realization, and to highlight the empirical research done on purpose of revealing influence of this kind of activity on the results of students' holistic training. In accordance with the aims of the paper, specific examples of such an experience are depicted in details. The empirical research, alos covered in the paper, demonstrated positive impact of the implemented project-oriented activity on building dynamic computer models and simulation activity with them on the results of students' holistic training, in particular, on their cognitive eagerness. The scopes of further research are outlined.

\section{REFERENCES}

1. Освітня реформа: результати та перспективи. Київ, 2019. URL: https://mon.gov.ua/storage/app/media/Serpneva\%20conferentcia/2019/Instit ut-osv-analitiki.pdf

2. Концепція Нової Української Школи. URL: www.nus.org.ua

3. Стан та перспективи розвитку природничо-математичної освіти в системі загальної середньої освіти в Україні. Київ, 2019. URL: http://www.soippo.edu.ua/index.php/home/3589-stan-i-perspektivi-rozvitkuprirodnicho-matematichnoji-osviti-v-sistemi-zagalnoji-serednoji-osviti-vukrajini

4. Singh K. Education for the Global Society', in Learning: The Treasure Within, The Report to UNESCO of the International Commission on Education for the Twenty First Century. Paris : UNESCO, 1996.

5. Holistic Education: An Approach for 21 Century. International Education Studies / S. Mahmoudi et al. 2012. V. 5. № 2. P. 178-186. 
6. Miller J. Holistic learning and spirituality in education: Breaking new ground. Albany : State University of New York Press. New York Press Ed., 2005.

7. Hacker M.: Integrating computational thinking into technology and engineering education. Technology and Engineering Teacher. 2018. 77 (4). $8-14$.

8. Зайцев Д.А. Математичні моделі дискретних систем : навчальний посібник. Одеса : ОНАЗ імені О. Попова, 2004. 40 с.

9. Shamshina Natalia. Solving Tasks Of Computer Modeling In Excel Spreadsheet. Physical and Mathematical Education. 2018. Issue 4 (18). P. 171-176.

10. Balogh Z., Kuchárik M. Student Learning Simulation Process with Petri Nets: Proceedings of ICCD. 2017. URL: https://www.researchgate.net/ publication/327188084_Student_Learning_Simulation_Process_with_Petri_ Nets_Proceedings_of_ICCD_2017

11. Peterson J. Petri net theory and the modeling of systems, Prentice Hall; 1 St edition, 1981. $290 \mathrm{p}$.

12. Petri Carl Adam, Reisig Wolfgang. Petri net. Scholarpedia. 2008. 3 (4). 6477. doi: $10.4249 /$ scholarpedia.6477

13. Zaitsev D.A. Toward the Minimal Universal Petri Net. IEEE Transactions on Systems, Man, and Cybernetics: Systems. 2013. 44. P. 47-58. doi:10.1109/TSMC.2012.2237549

14. Rogério Campos-Rebelo, Anikó Costa, Luís Gomes. Finding Learning Paths Using Petri Nets Modeling Applicable to E-Learning Platforms. 3rd Doctoral Conference on Computing, Electrical and Industrial Systems (DoCEIS). Costa de Caparica, Portugal, 2012. P. 151-160.

\section{Information about the authors:}

Bilousova L. I.,

Ph.D. in Physics-Mathematics Sciences, Full Professor, Professor at the Computer Science Department

Kharkiv National Pedagogic University 29, Alchevskyh str., Kharkiv, Ukraine

Gryzun L. E., Doctoral Degree in Pedagogic Sciences, Full Professor, Professor at the Computer Science Department Kharkiv National Pedagogic University 29, Alchevskyh str., Kharkiv, Ukraine 